\title{
Finding of Systrophia argentina n. comb. in the Argentine Precordillera (Mendoza province) a century and a half after its description (Mollusca: Gastropoda: Scolodontoidea)
}

\begin{abstract}
Sergio E. MIQUEL
'Museo Argentino de Ciencias Naturales "Bernardino Rivadavia", Avda. Ángel Gallardo 470, C1405DJR, Ciudad Autónoma de Buenos Aires, República Argentina. Consejo Nacional de Investigaciones Científicas y Técnicas (CONICET).E-mail: semsnail@yahoo.com.ar; semsnail@macn.gov.ar

Abstract: Systrophia argentina (Strobel, 1874) n. comb. is here re-described 150 years after its discovery. The specimens were found in the Argentine Precordillera (Quebrada San Isidro, Mendoza province, Argentina), at $2.000 \mathrm{~m}$, near the typical locality of the species, here restricted to the Angostura or garganta (gullet) of Villa Vicencio and Casa de Piedra. It is the southernmost distribution of the genus. This snail has a shell of medium size, planispiral, with six whorls; radula with central plate tricuspid, and latero-marginal teeth aculeate, formula: 13 - C - 13; vagina short, spermathecal duct reaching the distal extreme of the vagina, near the atrium; penial sheath long, penis occupying most of the penial sheath, epiphallus with a retractor muscle adhered to its extreme, large and quadrangular gland attached to the penial sheath; atrium very short. S. argentina is the only species of Systrophia L. Pfeiffer, 1855 in Argentina, being the most austral distribution of the genus
\end{abstract}

Key words: Scolodontidae, South America, Andes mountains, Mendoza province, genital apparatus, radula

Resumen: Hallazgo de Systrophia argentina n. comb. en la Precordillera argentina, a 150 años de su descripción (Mollusca: Gastropoda: Scolodontoidea). Systrophia argentina (Strobel, 1874) n. comb. es redescripta después de 150 años de su descubrimiento. Los ejemplares fueron encontrados en la Precordillera argentina (Quebrada San Isidro, provincia de Mendoza, Argentina), a 2.000 metros sobre el nivel del mar, cerca de su localidad típica. Ésta, aquí es restringida a Villa Vicencio y Casa de Piedra. Presenta una concha de tamaño mediano, planispiral, con 6 vueltas; rádula con placa central tricúspide, y dientes latero-marginales aculeados, fórmula: 13 - C - 13; vagina corta, ducto espermático alcanzando el extreme distal de la vagina, cerca del atrio; bolsa del pene larga, el pene ocupa la mayor parte de la bolsa peniana, epiphallus presenta un músculo retractor en su extremo; glándula cuadrangular grande adherida a la bolsa del pene; atrio muy corto. S. argentina es la única especie del género encontrada hasta el momento en la Argentina, siendo la distribución más austral de Systrophia L. Pfeiffer, 1855.

Palabras clave: Scolodontidae, South America, Andes mountains, Mendoza province, genital apparatus, radula

\section{INTRODUCTION}

In 1868, Pellegrino Strobel wrote his first comments about the continental mollusks of the Argentine Precordillera of Mendoza province. A few years later, in the same area, the author described a new species of Scolodontidae H.B. Baker, 1925, Hyalina (Ammonoceras) argentina Strobel, 1874, classified as Streptaxidae Gray, 1860. With no new specimens, Doering (1877) transferred the species to his new subgenus, Streptaxis (Scolodonta) Doering, 1877; a few years later, Tryon (1885) combined it to Streptaxis (Ammonoceras) L. Pfeiffer, 1855 (a synonymous junior of Happia Bourguignat,
1889 (Worms, 2020). In 1920, Frenguelli called Scolodonta argentina to fossil specimens from Pleistocene and Holocene of Córdoba and Entre Ríos (Argentina), but the specific identity of them is dubious (Miquel \& Aguirre, 2011).

The Scolodontidae is an interesting group of landshells inhabiting Central and South America, with numerous living species; recent studies consider it a clade of gastropods pulmonate (Ramírez et al., 2012; Worms, 2020). Systrophia L. Pfeiffer, 1855 is a characteristic genus of tropical areas of Venezuela, Colombia, Ecuador, Peru, Brazil and Bolivia (Ramírez et al., 2012, fig. 10), with species of large and thin shells, and spire very low. 
Several species of this family have an almost transparent shell, with a very colored body (white, yellow, orange or red). These species are carnivorous; they eat worms and other snails, being active and voracious (Ramírez, 1993). In Argentina, the family Scolodontidae includes the genera Scolodonta Doering, 1875, Happia Bourguignat, 1889, Drepanostomella Bourguignat, 1889, Miradiscops H.B. Baker, 1925 and Wayampia Tillier, 1980 (Fernández, 1973; Ramírez, 1993; Miquel et al., 2007; Hausdorf, 2006). Wayampia was later synonymized to Scolodonta (Bank, 2017). Happiela H.B. Baker, 1925 has been recorded by Ramírez (1993) for Argentina, but this mention is dubious. Here, Systrophia argentina (Strobel, 1874) n. comb. is re-described, based on new materials from the Precordillera of Mendoza province, Argentina. This is the first record of the species in the last 150 years and the first reliable cite of the genus Systrophia L. Pfeiffer, 1855.

\section{MATERIALS AND METHODS}

The specimens were housed in the Invertebrates Division of the Museo Argentino de Ciencias Naturales "Bernardino Rivadavia" (MACN-In), Buenos Aires, Argentina. They are stored in ethanol 70\%. The images of the radula were obtained in the Service of Scanning Electronic Microscopy of the MACN (Phillips XL Series 30 ), previously metalized with gold-palladium. The classification of Worms (2020) is followed; the number of whorls was counted according to Kerney \& Cameron (1979).

\section{RESULTS}

Scolodontidae

Systrophia L. Pfeiffer, 1855

Systrophia argentina (Strobel, 1874)

n. comb.

(Figs. 2-3)

Hyalina (Ammonoceras) Argentina Strobel, 1874: 9, Tav. 1, Fig. 1.

Streptaxis (Scolodonta) Argentina Doering, 1877: 310.

Streptaxis (Scolononta) (sic) Argentina Doering, 1878: 229.

Streptaxis (Ammonoceras) Argentina Tryon, 1885: 66, pl. 13, Figs. 58-60.

? Scolodonta argentina Frenguelli, 1920: 162, 249.

? Scolodonta argentina Miquel \& Aguirre, 2011: 123, Fig. 35.

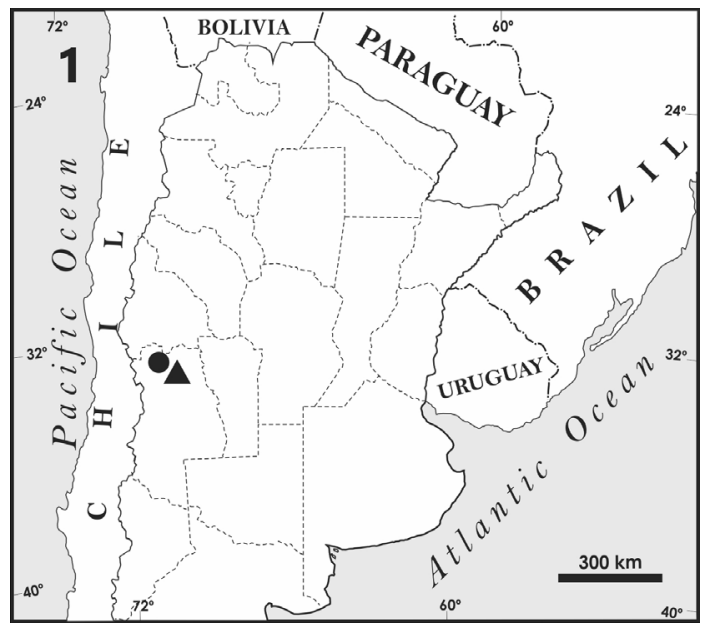

Fig. 1: Location of area where the species were found ( $\Delta)$ and the typical locality restricted ("Angostura" or "garganta" of Villa Vicencio and Casa de Piedra, Precordillera, Argentina) (•).

Diagnosis. Shell small, planispiral, 5- 6 whorls, protoconch with almost 2 whorls; radula with teeth aculeate, formula: $13-\mathrm{C}-13$; vagina and atrium short; spermathecal duct reaching the distal extreme of the vagina; penial sheath with some circumvolutions; penis occupying most of the penial sheath; large and quadrangular gland ("penial gland") attached to the distal extreme of the penial sheath.

Description. Shell small $(6-4.55 \mathrm{~mm}$ in adult stage), planispiral, $5.00-5.50$ whorls, semitransparent (height low $(2.00-1.69 \mathrm{~mm})$, almost smooth, slow growth, suture deep, umbilicus large and perspective $(1.95-1.82 \mathrm{~mm})$, aperture circular $(1.43-1.30 \mathrm{~mm})$, peristome slightly expanded, superior edge of the peristome a bit descendent and oblique, growth lines scarcely marked, more marked on the first adult whorls, body yellowish, protoconch with almost 2 whorls, smooth (Fig. 2A-D, Table 1). Radula with central plate tricuspid, and latero-marginal teeth aculeate, typical of the family: $13-\mathrm{C}-13$ (Fig. 2E-F). Genital tracts very long and slim. Gonadal hermaphrodite acini cream, spermatheca ( or seminal vesiculae) and hermaphroditic duct typical ones; spermioviduct, albumen gland and prostate elongated; fertilization sac medium size; long and convolutioned free oviduct; vagina short (oviduct + vagina: $2.75 \mathrm{~mm}$ aprox.); spermatheca claviform, spermathecal duct very long (3.5 $\mathrm{mm}$ aprox.), reaching the distal extreme of the vagina, near the atrium; long penial sheath, 


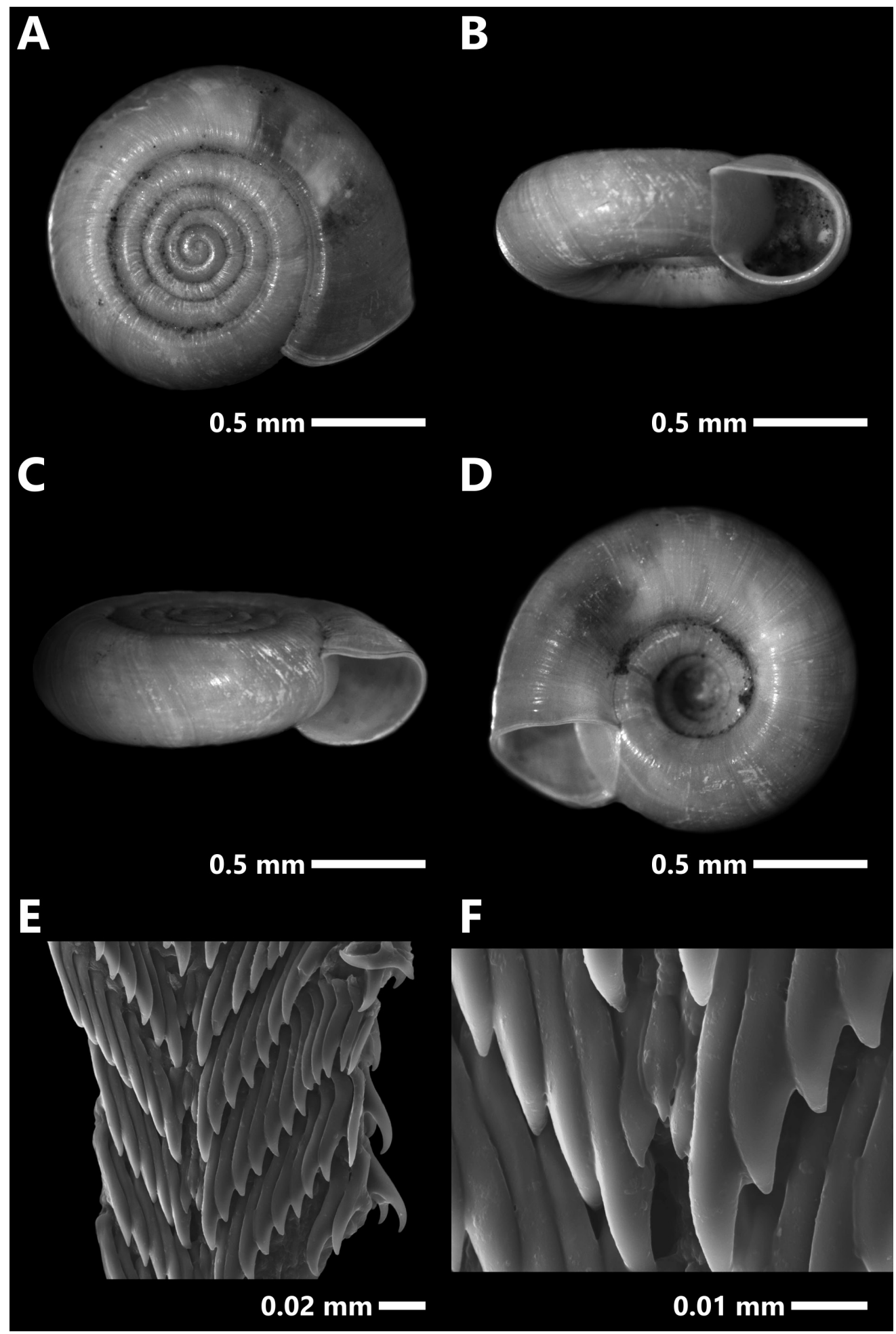

Fig. 2 A-F: Systrophia argentina (Strobel, 1874). MACN-In 42446. Quebrada San Isidro, 2.050 masl. Precordillera Mendoza province, Argentina. A. Apical view. B-C. Apertural view. D. Umbilical view. Radula. E. General view. F. Detail of central plate. 


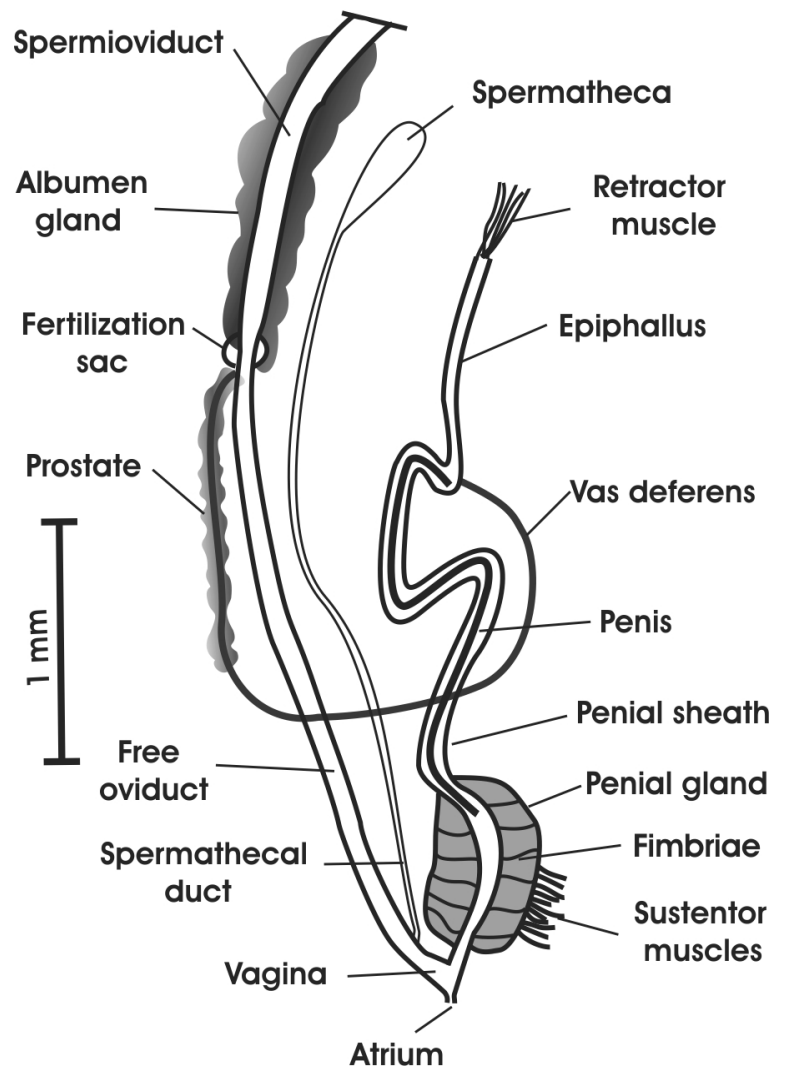

Fig. 3: Systrophia argentina (Strobel, 1874). MACN-In 42446. Quebrada San Isidro, $2.050 \mathrm{msnm}$. Precordillera, Mendoza province, Argentina. Genital apparatus. with some circumvolutions; penis occupying most of the penial sheath, vas deferent penetrating laterally at the base of the penis; epiphallus with a retractor muscle adhered to its extreme (epiphallus + penial sheat: $4 \mathrm{~mm}$ aprox.); large and quadrangular gland ("penial gland") attached to the distal extreme of the penial sheath, with some sustentor muscles, the walls of this gland are internally fimbriated; atrium very short (Fig. 3; Table 1).

Typical locality. "Angostura" or "garganta" (gullet) of Villa Vicencio and Casa de Piedra, Precordillera, Argentina (here restricted) (Fig. 1). Distribution. Argentina: Mendoza province: Precordillera, $c a$. 2,000 m. Found on the ground with Artemisia echegarayi Hieron. (Asteraceae) and specimens of Scolodonta semperi Doering, 1875 (Fig. 1).

Materials studied. S. argentina: MACNIn 42446. Argentina: Precordillera, Mendoza province. Quebrada San Isidro, 2,050 m asl. 4/ IV/1983. C. and A. Roig. 3 exs. in ethanol (1 ex. complete, 2 exs. dissected with their soft parts, and 1 radula metallized. S. semperi. MACN-In 42284. Similar locality. 2 exs. in ethanol. S. cere- onitens Haas, 1951. MACN-In 29466. N-Peru, to the south of San Ignacio, valley of the Chinchipe river. Col. and det. W. Weyrauch. 5 exs.

Taxonomic remarks. The type series is lost. Strobel (1874) described this Argentine species based on specimens larger than those here analyzed (6 mm). Frenguelli (1920) cited this species for the Ensenadan ("pre-bonaerian") age -middle Pleistocene- from the cities of Córdoba (Córdoba province) and Paraná (Entre Ríos province), and in recent loess in Paraná; however, the specimens studied by this author are not co-specific with $S$. argentina and could be a species of Scolodonta (Miquel \& Aguirre, 2011). So far, $S$. argentina has not been found in the other areas indicated by Strobel (1874): Napostá Grande valley and Sierra de la Ventana (Buenos Aires province). Thus, it is considered necessary to restrict the typical locality to the localities of Mendoza province.

Hyalina (Ammonoceras) argentina is included in the genus Systrophia due to the following features: shell discoid, whorls that grow slowly, last whorl not larger than previous whorls, apertural teeth absent, genital ducts very long and 
Table 1. Measurements of Systrophia argentina (Strobel, 1874) (*shell and body lost, dissected for radula and genitalia).

\begin{tabular}{lccccc}
\hline & Main diameter & Height & Whorls & Umbilicus & Aperture \\
\hline Original material (lost) & 6 & 2 & 5 & --- & -- \\
MACN-In 42446 (adult) & 4.68 & 1.82 & 5.50 & 1.82 & $1.30 \times 1.30$ \\
MACN-In 42446* & 4.55 & 1.69 & 5.50 & 1.95 & $1.43 \times 1.43$ \\
MACN-In 42446 (young) & 3.64 & 1.30 & 4.75 & 1.30 & $1.17 \times 1.30$ \\
\hline
\end{tabular}

thin, similar to generic model (Ramírez, 1993). Now, Hyalina S. Studer, 1820 is a synonym of Vitrina Draparnaud, 1801 (Vitrinidae Fitzinger, 1883), and Ammonoceras L. Pfeiffer, 1855 is a synonym of Happia (Zilch, 1960; Bank, 2017).

An uncommon feature found in S. argentina is the penial gland (Fig. 3). This large gland does not seem to be present in other genera and species of Scolodontidae; an "atrial gland" of similar location has been described in Tamayoa sp. (from uncertain locality) (Ramírez, 1993), whereas an "organe amatorial" ("organ of love") has been described in T. (Tamayops) decolorata (Drouët, 1859), from Cayenne (French Guiana) (Tillier, 1980). The former structure could be homologous to the gland of $S$. argentina, not so the latter, which has an apparent mechanical, not glandular, function.

Systrophia argentina is different from Scolodonta spp. in the larger size, more number of whorls, and the planispiral coiling. $S$. semperi, which inhabits north and central Argentina, has a smaller discoid shell, genital ducts thickened, atrium long, vagina short, and deferent duct inserted in the proximal extreme of the epiphallus (Hylton Scott, 1945; Hausdorf, 2006). S. argentina is different from the species of Happia in the shell morphology, which, in the latter is subcircular to subdiscoidal, with whorls with fast growing (Ramírez, 1993). The species of Happia found in Argentina are H. skiaphila (d'Orb., 1835) and H. ordinaria (Smith, 1881) (Hylton Scott, 1948, 1972). The former species lives in the north of the country, measures 11 $\mathrm{mm}$, has 7 whorls and genital ducts thick and convolutioned, principally those of the male via (Hylton Scott, 1948), and was classified as Wayampia by Ramírez (1993). Happia ordinaria, from Patagonia, has a width of $3 \mathrm{~mm}, 3.5$ whorls with fast growing, and radula with the formula $12-\mathrm{C}-12$, where there are lateral teeth tricuspid and monocuspid (Hylton Scott, 1972), very different from those of S. argentina.
The austral distribution of Systrophia reaches Bolivia (Ramírez, 1993; Ramírez et al., 2012), so, $S$. argentina could be considered a relict species, surviving in a warm and slightly humid mountainous area, being the distribution more austral for the genus. According to Strobel (1874), this species coexists with Bostryx mendozanus (Strobel, 1874), B. cordillerae (Strobel, 1874) and B. cuyana (Strobel in Pfeiffer, 1867) (Breure, 1979; Miquel, 1995).

\section{ACKNOWLEDGEMENTS}

I wish to thank A. Roig (MACN-CONICET) for the donation of the materials of S. argentina and S. semperi for this study. The author belongs to the Career of Scientific Researcher of the Consejo Nacional de Investigaciones Científicas y Técnicas (CONICET) of Argentina.

\section{REFERENCES}

Breure, A. S. H. 1979. Systematics, phylogeny and zoogeography of Bulimulinae (Mollusca). Zoologische Verhandelingen 168: 3-215, 3 pls.

Doering, A. 1874 [1875]. Estudios sistemáticos y anatómicos sobre los moluscos pulmoníferos de los países del Plata. Periódico Zoológico 1 (3): 129-204, fig. 4.

Doering, A. 1875 [1878]. Suplementos II de la lista de moluscos terrestres y fluviales en el territorio del Río de la Plata y de la República Argentina. Periódico Zoológico 2 (4): 258-259.

Doering, A. 1876 [1877]. Apuntes sobre la fauna de moluscos de la República Argentina (Tercera parte). Boletín de la Academia Nacional de Ciencias Exactas en Córdoba 2 (3): 300-339.

Fernández, D. 1973. Catálogo de la malacofauna terrestre argentina. Monografías, 4. Comisión de Investigaciones Científicas, La Plata. 197 pp.

Frenguelli, J. 1920. Contribución al conocimiento de la geología de Entre Ríos. Boletín de la Academia Nacional de Ciencias en Córdoba 24: 55-256.

Hausdorf, B. 2006. The systematic position of Scolodonta Döring, 1875 and Scolodontidae H.B. Baker, 1925 (Gastropoda: Pulmonata). Zoologischee Anzeiger 245: 161-165.

Hylton Scott, M. I. 1945. Fáunula malacológica de Til- 
cara. Revista del Museo de La Plata (Nueva serie) 4, Zool., 28: 195-211.

Hylton Scott, M. I. 1948. Moluscos del noroeste argentino. Acta Zoológica Lilloana 6: 241-274.

Hylton Scott, M. I. 1972. Lista de Gastropoda terrestres, principalmente Endodóntidos de Tierra del Fuego, Isla de los Estados e islotes vecinos. Neotropica 18 (56): 67-72.

Kerney, M.P. \& R.A.D. Cameron. 1979. A field guide to the land snails of Britain and North-west Europe. Ed. Collins. 228 pp. London.

Miquel, S. E. 1995. Las especies del género Bostryx Troschel 1847 (Gast. Stylom. Bulimulidae) en la República Argentina (segunda y última parte). Archiv für Molluskenkunde 124 (1/2): 119-127.

Miquel, S. E. \& M. L. Aguirre. 2011. Taxonomía de los gasterópodos terrestres del Cuaternario de $\mathrm{Ar}$ gentina. Revista Española de Paleontología 26 (2): 101-133.

Miquel, S. E., A. Tablado \& A. Sodor. 2007. Curaduría en la Colección Nacional de Invertebrados de Argentina: aportes a la biodiversidad y biogeografía de Gasterópodos terrestres argentinos. Comunicaciones de la Sociedad Malacológica del Uruguay 9 (90): 113-115.

Ramírez, R. L. 1993. A generic analysis of the family
Systrophiidae (Mollusca: Gastropoda): taxonomy, phylogeny and biogeography. Thesis. University of Kansas. Lawrence. 218 pp.

Ramírez, R., V. Borda, P. Romero, J. Ramírez, C. Congrains, J. Chirinos, P. Ramírez, L.V. Velásquez \& K. Mejía 2012. Biodiversidad y endemismo de los caracoles terrestres Megalobulimus y Systrophia en la Amazonía occidental. Revista Peruana de Biología 19 (1): 59-74.

Strobel, P. 1868. Alcune note di Malacologia Argentina. Atti della Societá italiana di scienze naturalli 11 (3): 1-7.

Strobel, P. 1874. Materiali per una malacostatica di terra e di acqua dolce dell'Argentinia Meridionale. Biblioteca Malacologica 1: 3-105, 2 tavs.

Tillier, S. 1980. Gasterópodes terrestres et fluviátiles de Guyane Française. Mémoires du Muséum National d'Histoire naturelle, Nouvelle série, Série A, Zoologie, 118: 3-186, 6 pls.

Tryon, G. W. 1885. Testacellidae, Oleacinidae, Streptaxidae, Helicoidea, Vitrinidae, Limacidae, Arionidae. Manual of Conchology, 1: 5-364, 60 pls. Philadelphia.

Worms (World Register of Marine Species). 2020. http://www.marinespecies.org at VLIZ. Accessed 2020-07-24. doi:10.14284/170.

Doi: 10.22179/REVMACN.22.677

Recibido: 4-III-2020

Aceptado: 5-IX-2020 